\title{
Evaluation on Hydnophytum formicarum Tuber from Setiu Wetland (Malaysia) and Muara Rupit (Indonesia) for Antibacterial and Antioxidant activities, and anti-cancer Potency against MCF-7 and HeLa Cells
}

\author{
Yosie Andriani $^{1 *}$, Habsah Mohamad ${ }^{1}$, Murni Nur Islamiah Kassim ${ }^{1}$, Nur Diyana Rosnan ${ }^{2}$, Desy Fitrya Syamsumir ${ }^{1}$, \\ Jasnizat Saidin $^{1,3}$, Tengku Sifzizul Tengku Muhammad ${ }^{1}$, Hermansyah Amir ${ }^{4}$ \\ ${ }^{1}$ Institute of Marine Biotechnology, Universiti Malaysia Terengganu, 21030, Kuala Terengganu, Terengganu, Malaysia. \\ ${ }^{2}$ Food Sciences and Technology, Universiti Malaysia Terengganu, 21030, Kuala Terengganu, Terengganu, Malaysia. \\ ${ }^{3}$ School of Marine and Environmental Sciences, Universiti Malaysia Terengganu, 21030, Kuala Terengganu, Terengganu, Malaysia. \\ ${ }^{4}$ Educational Chemistry Program, Faculty of Teacher Training and Education, Bengkulu University, Bengkulu, Indonesia.
}

\begin{tabular}{l} 
ARTICLE INFO \\
\hline Article history: \\
Received on: 20/07/2017 \\
Accepted on: $28 / 08 / 2017$ \\
Available online: $30 / 09 / 2017$ \\
\hline Key words: \\
Hydnophytum formicarum; \\
DPPH; Antibacterial; \\
Apoptosis; MCF-7; HeLa.
\end{tabular}

\begin{abstract}
This current study is to evaluate and compare the antibacterial, antioxidant and anticancer activity of $H$. formicarum tubers from Setiu Wetland, Terengganu, Malaysia and inland forest of Muara Rupit, SumateraSelatan, Indonesia. The tubers were extracted using methanol and then sequentially fractioned using solvent partitioning by $n$-hexane, dichloromethane, and ethyl acetate. The phytochemical study showed that samples from both places possessed same phytochemicals content that was rich with phenols, tannins, steroids, and glycosides. Extract from Setiu exhibit antibacterial activity against all tested bacteria, while methanol extract from Muara Rupit was only active against Gram positive bacteria. All samples showed high DPPH free radical scavenging activity ( IC $_{50}$ less than $10 \mu \mathrm{g} / \mathrm{ml}$ ). Via MTS assay, no cytotoxic activity of all samples was observed against HeLa cells. Only a fraction from Setiu Wetland showed very strong cytotoxic activity against MCF-7 cells $\left(\mathrm{IC}_{50}=2 \mu \mathrm{g} / \mathrm{ml}\right)$ and its morphological features stained by Annexin-V/PI and DAPI showed that the cell death was mediated by apoptosis. Results revealed that $H$. formicarum tuber from Setiu wetland and Muara Rupit showed very good potency as antibacterial and antioxidant agents. The only sample from Setiu wetland has a good potency as anticancer against MCF-7 cells but not against HeLa cells.
\end{abstract}

\section{INTRODUCTION}

Cancer is number one killer in the world with mortality reported around 8.8 million deaths in 2015 (WHO, 2017) and expected to grow to 12 million deaths in 2030 (WHO, 2014). American Cancer Society in 2016 estimated 57,740 new cancer cases and 16,910 cancer deaths will occur among Asian Americans, Native Hawaiians, and Pacific Islanders. The most common causes of cancer death in 2015 reported by WHO (2017)

\footnotetext{
* Corresponding Author

Yosie Andriani, Institute of Marine Biotechnology,

Universiti Malaysia Terengganu, 21030, Kuala Terengganu,

Terengganu, Malaysia. Email: yosieandriani @ gmail.com
}

are cancers of lung (1.69 million deaths), liver (788 000 deaths), colorectal (774 000 deaths), stomach (754 000 deaths), and breast (571 000 deaths). In 2015, approximately 40,290 women are expected to die from breast cancer (ACS, 2015). Breast cancer is number one of the leading causes of cancer deaths among woman in the world, whereas, cervical cancer is the fourth most common cancer in the women (WHO, 2014). Cervical cancer caused an estimated 266,000 deaths worldwide in 2012 which nominated about $7.5 \%$ of cancer mortality in females. In a less developed country, an estimated nine out of ten accounting for $87 \%$ cervical cancer deaths have reported (Globocan, 2014). There are many treatments have been introduced to cure cancer such as chemotherapy, radiotherapy, and surgery. 
These therapies have side effects which affected differently among cancer's patient. Thus, it is important to find natural sources of anticancer which have less or no side effect to the patients compared to present medical treatment. Alternative treatment using herbal traditionally have been used since a long time in many Asian countries, such as Thailand, India, Indonesia, China, and Malaysia. Malaysia is a country that rich in biodiversity as a potential source of secondary metabolites and the primary metabolite. Setiu Wetlands is a part of the Setiu River Basin in Terengganu, Malaysia, it is a place with a huge amount of wildlife (WWF, 2008). The Setiu Wetlands has abundance in utilizable natural resources of plants such as Melaleuca, Pandanus, mangroves, and Hydnophytum. In Setiu, Hydnophytum can be abundantly found as epiphytes on mangrove trees (Fig 1a). Its local name is kepalaberuk in Terengganu, Malaysia and antnests (sarangsemut) in Malaysia, Thailand, and Indonesia. According to Soeksmanto et al. (2010), this plant lives as epiphytes on plants such as cajuput (Melaleuca), "Cemaragunung" (Casuarina), Kaha (Castanopsis) and Beech (Nothofagus). There is two genus of kepalaberuk in Setiu wetland, they are $H$. formicarum and Myrmecodia tuberose which have characteristic similar to sarangsemut from Papua (Myrmrcodi pendens) originate from the same family, Rubiaceae. At Muara Rupit, Sumatera Selatan, Indonesia, H. formicarum lives on a higher plant, such as Durio zibethinus. Different environmental and habitat will probably have resulted in differences metabolites medicinal property.

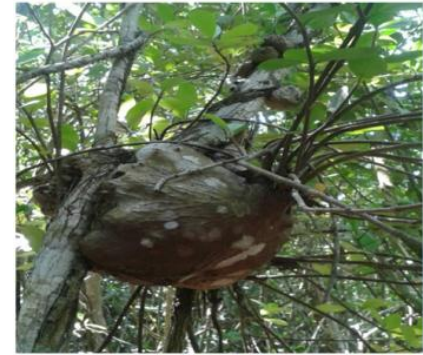

(a)

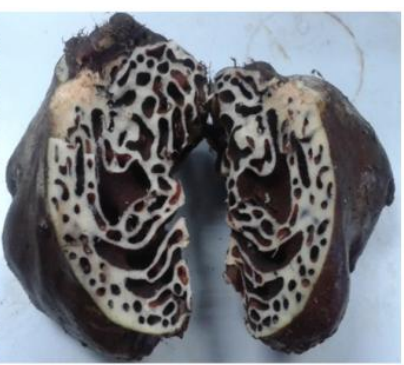

(b)
Fig. 1: Hypnophytum formicarum plant (a) and its tuber (b).

People believed that tuber of $H$. formicarum tuber (Fig.1b) can be used as a medication for diabetic, high blood pressure, headache, fever, skin rashes, and cancer. The previous study suggesting that $H$. formicarum tuber is rich in chemical constituents such asaldehyde/ketone, terpenoids, plant phenolics include flavonoids and tannins, and other phenolic contents (Darwis et al., 2014). The potential H. formicarum tuber in reducing fevers and skin rashes supposedly associated with its ability to cure an infection that caused by bacteria. Current study reported that $H$. formicarum crude extracts and protocatechualdehyde, an isolated compound from ethyl acetate crude extract of $H$. formicarum tuber were showed antibacterial activity against Plesiomonass higelloides bacteria (Prachayasittikul et al., 2008). The tuber of H. formicarum has efficacy to cure for many diseases, however scientific study of this plant tuber is still limited. According to the author's, the antibacterial and anticancer potencies of H.formicarum tuber from Setiu wetland, Kuala Terengganu, Malaysia as well as Muara Rupit, Sumatera Selatan, Indonesia have not published elsewhere. Thus, the aims of this study are to investigate antibacterial, antioxidant, and anticancer potency of $H$. formicarum tuber from both places on breast cancer cells (MCF-7) and cervical cancer cells (HeLa) by looking their cytotoxicity property and morphology.

\section{MATERIAL AND METHODS}

Sample collection, preparation, extraction, and fractionation

Sample of $H$. formicarum tubers were collected from mangrove trees (Rhizophora apiculata and Heritera littoralis) at Setiu wetland, Kuala Terengganu, Malaysia. The samples were collected on July 2014. While samples from Muara Rupit, Sumatera Selatan, Indonesia were collected from Durio zibethinus trees on Mei 2014. The voucher specimens of samples have been deposited at Institute of Marine Biotechnology, Universiti Malaysia Terengganu with the voucher numbers are TER0315001 (Setiu Wetland) and TER0315002 (Muara Rupit).The samples were cut into small pieces, lyophilized using freeze dryer for $48 \mathrm{~h}$ and then ground to a powdered form. Powder of $H$. formicarum tubers from both places were weighed (750 g each). Then, they were soaked in methanol for 5 days and were filtered using filter paper. The extraction process were repeated until extract became colorless. The filtrate were then dried using the rotary evaporator at $40^{\circ} \mathrm{C}$ to get methanol extracts (HFMs and HFMm). Both of methanol extracts were then sequentially fractioned using solvent partitioning by $n$-hexane (HFHs and HFHm), dichloromethane (HFDs and HFDm), and ethyl acetate (HFEs and HFEm). All samples were kept in the freezer until used for the further test.

\section{Reagents}

Vincristine sulfate and MEM media were purchased from Santa Cruz(Santa Cruz, CA, USA) and Nacalai, (Nacalai Tesque, Kyoto Japan),respectively. While Fetal Bovine Serum (FBS), 1\% non-essential amino acid, $1 \%$ sodium pyruvate, and $1 \%$ penicillin, streptomycin, and Mueller Hinton agar (MHA) were purchased from GibcoDiagnostics (Madison, WI, USA). Annexin V and propidium iodide (PI) were purchased from Fluos and Fluka (Steinheim, Germany), respectively. Quercetin, 4', 6-diamidine-2'phenylindole dihydrochloride (DAPI), DPPH, and others chemicals, solvents and reagents were of analytical grade and purchased from Sigma Aldrich (Steinheim, Germany).

\section{Phytochemicals screening}

Phytochemicals screening of methanol extracts from $H$. formicarum tuber were adapted from Yadav and Agarwala (2011) as described in Andriani et al. (2015). Test for phenols and tannins, $2 \mathrm{ml}$ of $2 \%$ ferric chloride solution was added to the methanol extracts. A blue-green to black color indicates the presence of phenols and tannins. Test for flavonoids, methanol extract was mixed with $2 \mathrm{ml}$ of $2 \%$ sodium hydroxide solution. An 
intense yellow color was formed turned to colorless on an addition of few drops of diluted acid indicated the presence of flavonoids. Test for steroids, methanol extract was mixed with $2 \mathrm{ml}$ of chloroform and concentrated $\mathrm{H}_{2} \mathrm{SO}_{4}$ was added sidewise of a test tube. A red color produced in the lower chloroform layer indicated the presence of steroids. Test for terpenoids, methanol extract was dissolved in $2 \mathrm{ml}$ of chloroform and evaporated to dryness. Then 2 $\mathrm{ml}$ of concentrated sulfuric acid was added and heated for about 2 min. A grayish color of mixture indicated the presence of terpenoids. Test for alkaloids, methanol extract was mixed with 2 $\mathrm{ml}$ of $1 \% \mathrm{HCl}$ and heated gently. Mayer's and Wagner's reagent were then added to the mixture. Turbidity precipitate formed shows the positive result for the presence of alkaloids. Test for saponins, methanol extract was diluted with $5 \mathrm{ml}$ of distilled water in a test tube. The mixture was shaken vigorously. The formation of stable foam indicated the presence of saponins. Test for glycosides, methanol extract was mixed with $2 \mathrm{ml}$ of glacial acetic acid containing 1-2 drops of $2 \%$ ferric chloride solution. The mixture was then poured into another test tube containing $2 \mathrm{ml}$ of concentrated sulfuric acid carefully. A brown ring interphase shows the positive result for the presence of cardiac glycosides.

\section{Determination of DPPH free radical scavenging activity}

A quantitative analysis using 1, 1-diphenyl-2-picryl hydrazyl (DPPH) free radical scavenging assay (Kumaran and Karunakaran, 2006) using the Quercetin as a positive control and dimethyl sulfoxide (DMSO) as a negative control. Samples stock were diluted in DMSO and were prepared in varying concentration by twofold serial dilution in DMSO with concentrations of 10, 5 , $2.5,1.25,0.625,0.313,0.156 \mathrm{mg} / \mathrm{ml}$ in 96 well plates. DPPH reagent was prepared with $0.04 \% \quad(\mathrm{w} / \mathrm{v})$ concentration by dissolving $2.37 \mathrm{mg}$ of the DPPH powder in $100 \mathrm{ml}$ methanol solution. DPPH solution was shaken and covered with aluminum foil to minimize the penetration of light. Two hundred microliter of methanolic DPPH solution (6 x 10-5 M) was added to all wells and the mixture was covered with aluminum foil and incubated for $30 \mathrm{~min}$ at room temperature. Then, the absorbance was measured at $517 \mathrm{~nm}$ using Elisa reader (Multiskan Ascent, Thermo Electron Corporation).

Free radical scavenging activity was determined according to the equation:

Free radical scavenging activity $(\%)=\frac{A c-A s}{A c} \times 100 \%$

where $A_{S}$ is the absorbance of the sample. $A_{C}$ is the absorbance of a negative control.

\section{Antibacterial activity}

Agar well diffusion method was used to analyze the antibacterial activity of samples compare to some antibiotics as control.

\section{Sub-culture of bacteria}

Selected Gram positive bacteria (B. cereus, B. subtilis, S.aureus, and Micrococcus sp.) and Gram negative bacteria
(E. coli, K. pneumonia, $P$. aeruginosa, Salmonella sp.) were subcultured in MHA at $37{ }^{\circ} \mathrm{C}$ for $24 \mathrm{~h}$ and used as a test medium for antibacterial susceptibility testing.

The bacteria cultured were then diluted in sterilized $\mathrm{dH}_{2} \mathrm{O}$ and concentration was adjusted by using densitometer at 0.5 McFarland $\left(1.0 \times 10^{8} \mathrm{CFU} / \mathrm{ml}\right)$.

\section{Sample preparation and anti-bacteria test}

Twenty milligrams of each methanol extract was added in $1 \mathrm{ml}$ of DMSO. Six serial dilutions yielded at concentrations of $20,10,5,2.5,1.25$ and $0.625 \mathrm{mg} / \mathrm{ml}$ for each extract. The bacterial inoculum was uniformly spread using sterile cotton swab on the surface of Mueller-Hinton agar plate. Then the agar was cut at diameter of $6 \mathrm{~mm}$ and carefully removed by using forceps sterilized by flaming. Forty micro liter of sample was loaded into each well and DMSO was used as negative control. Antibiotic discs were used as positive control (ampicillin, gentamycin, penicillin and tetracycline). The petri disks were incubated for 24 h at $37^{\circ} \mathrm{C}$.

\section{Cytotoxicity property against MCF-7 and HeLa cells 3-(4,5-dimethylthiazol-2-yl)-5-(3-carboxymethoxyphenyl)-2-(4- sulfophenyl)-2H-tetrazolium (MTS) Assay}

Cytotoxicity activity was performed by usingthe MTS assay with slightly modification (Chow et al., 2009). The cells were maintained in minimal essential medium (MEM) supplemented with $10 \%$ FBS, $1 \%$ non-essential amino acid, $1 \%$ sodium pyruvate and $1 \%$ penicillin streptomycinat $37{ }^{\circ} \mathrm{C}$ in $5 \%$ (v/v) $\mathrm{CO}_{2}$ incubator. For the assay, $100 \mu \mathrm{l}$ of exponentially grown cellswere seeded in 96-well plate at $5 \times 10^{3}$ cells/well and incubated for $24 \mathrm{~h}$. Subsequently, $100 \mu \mathrm{l}$ of the prepared extracts were added to the wells at the final concentrations of 100, 50, 25, $12.5,6.25,3.125,1.5625$ and $0.78125 \mu \mathrm{g} / \mathrm{ml}$ and were further incubated for $72 \mathrm{~h}$. Treatment at each concentration was carried out in triplicates and vehicle-treated cells were designated as untreated control.Aftertreatment, cell viability was measured by adding $20 \mu \mathrm{l}$ fresh MTS solution $(5 \mathrm{mg} / \mathrm{ml}$ in PBS) into each well. The plate then was incubated for $4 \mathrm{~h}$ at $37{ }^{\circ} \mathrm{C}$. The plate was left for 60 minutes before measuring the Optical Density (OD) by using ELISA reader at $490 \mathrm{~nm}$ reference wavelengths. The activity was expressed as $\mathrm{IC}_{50}$ (the concentration that inhibits $50 \%$ of cell growth).

\section{Determination of apoptotic cell death}

Cells were seeded at $5 \times 10^{3}$ cells/well in 96-well plateand incubated for $24 \mathrm{~h}$. Subsequently, medium was discarded and replaced with new medium containing extract at the final concentration of $\mathrm{IC}_{50}$ value, vincristine sulfate (positive control) and vehicle (negative control). After $24 \mathrm{~h}$ incubation, medium was discarded and Annexin-V/PI/DAPI reagent was added to each well. Cells were then incubated for $10-15 \mathrm{~min}$ at $15-25^{\circ} \mathrm{C}$. The morphological feature of apoptosis cells was analyzed by ImageXpress Micro XLS Widefield High-Content Analysis System (HCS) (Sunnyvale, USA). 


\section{Data analysis}

All the experiments in this current study were conducted in triplicate and the data are presented as mean values \pm standard deviation.

\section{RESULTS}

\section{Crude extract and Fractions}

The mass of methanol extracts and fractions were weighted and labeled as methanol extracts (HFMs, $18.23 \mathrm{~g}$; HFMm, $19.17 \mathrm{~g}$ ), $n$-hexane fractions (HFHs, $2.15 \mathrm{~g}$; HFSm, 2.23 $\mathrm{g}$ ), dichloromethane fractions (HFDs, $0.45 \mathrm{~g}$; HFDm, $0.39 \mathrm{~g}$ ), and ethyl acetate fractions (HFEs, $14.4 \mathrm{~g}$; HFEm, $13.8 \mathrm{~g}$ ). The yield of methanol crude extract and various fractions from both samples shown almost identical in quantity.

\section{Phytochemicals screening}

The observation of phytochemicals screening revealed that the same of chemicals constituents present in the $H$. formicarum tuber from both places, namely phenols/tannins, glycosides, and steroids (Table 1). Phenols/tannins showed by the blue-green or black colour appear after the extract was mixed with $2 \mathrm{ml}$ of $2 \% \mathrm{FeCl}_{3}$, while a reddish brown color indicated the presence of steroids after extract was mixed with chloroform and then concentrated Sulfuric acid. Lastly, steroids present showed by a red colour produced in the lower chloroform layer after the extract was mixed with chloroform, concentrated sulphuric acid and $\mathrm{C}_{2} \mathrm{H}_{4} \mathrm{O}_{2}$, respectively.

Table 1: Phytochemicals screening result for methanol extract of $H$. formicarum tuber (HFM).

\begin{tabular}{cccc}
\hline \multirow{2}{*}{ No. } & Phytochemicals & \multicolumn{2}{c}{ Result } \\
\cline { 3 - 4 } & & $\begin{array}{c}\text { HFMs from Setiu } \\
\text { Wetland (Malaysia) }\end{array}$ & $\begin{array}{c}\text { HFMm from Muara } \\
\text { Rupit (Indonesia) }\end{array}$ \\
\hline 1 & Phenols/tannins & + & + \\
2 & Flavonoids & - & - \\
3 & Saponins & - & - \\
4 & Glycosides & + & + \\
5 & Steroids & + & + \\
6 & Terpenoids & - & - \\
7 & Alkaloids & - & - \\
\hline$+:$ Phytochemicals present in the sample &
\end{tabular}

\section{DPPH free radical scavenging activity}

The result of antioxidant screening on all fractions of $H$. formicarum tuber from Setiu Wetland showed free radical scavenging activity (Fig.2a). Fractions of HFEs was revealed highest activity $\left(\mathrm{IC}_{50}=0.2 \mu \mathrm{g} / \mathrm{ml}\right)$ followed byHFMs $\left(\mathrm{IC}_{50}=7.3\right.$ $\mu \mathrm{g} / \mathrm{ml})$ and $\mathrm{HFHs}\left(\mathrm{IC}_{50}=8.3 \mu \mathrm{g} / \mathrm{ml}\right)$. The lowest activity was obtained by HFDs which didn't exceed the $\mathrm{IC}_{50}$ value. Quercetin as an antioxidant standard was shown DPPH free radical scavenging activity quite similar to the HFEs with the $\mathrm{IC}_{50}$ value of $0.3 \mu \mathrm{g} / \mathrm{ml}$. Furthermore, Fig. $2 \mathrm{~b}$ shows at the concentration tested up to $10 \mu \mathrm{g} / \mathrm{ml}$, all the fraction of $H$. formicarum tuber from Muara Rupittested have shown free radical scavenging activity. The values of scavenging activity decreased in the following order HFEm, HFMm, HFHm, and HFDm with the $\mathrm{IC}_{50}$ value in a range of $0.2 \mu \mathrm{g} / \mathrm{ml}$ to $4.1 \mu \mathrm{g} / \mathrm{ml}$. The lowest activity obtained by HFDm which didn't reach the $\mathrm{IC}_{50}$ value. Overall, ethyl acetate fractions from both places possess high free radical scavenging activity compared to the Quercetin $\left(\mathrm{IC}_{50}\right.$ value at $\left.0.3 \mu \mathrm{g} / \mathrm{ml}\right)$.

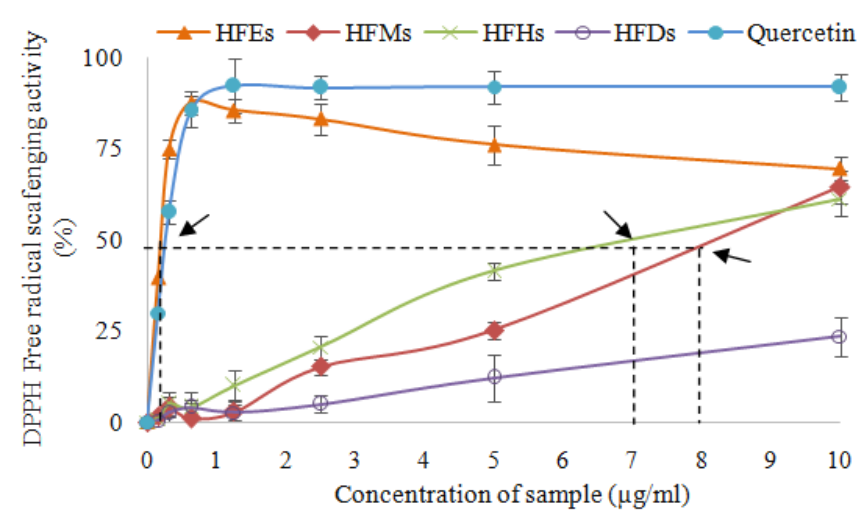

A

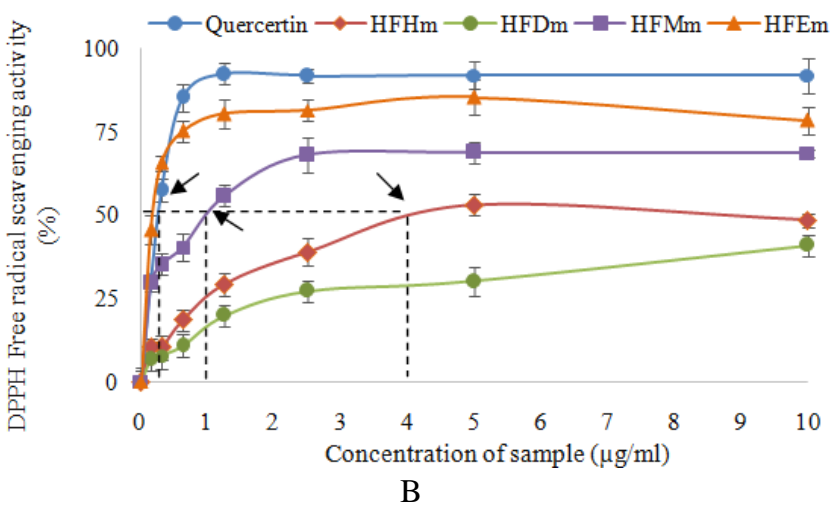

Fig. 2: DPPH free radical scavenging activity of $H$. formicarum tuber fromSetiu Wetland (a) and Muara Rupit (b). Black arrow indicated as $\mathrm{IC}_{50}$ value.

\section{Antibacterial activity}

Table 2 shows that almost all samples exhibited antibacterial activity at varying minimum inhibition concentration (MIC).Sample of $H$. formicarum tuber from Setiu Wetland (HFMs) was possessed a very good antibacterial activity against all Gram positive and Gram negative bacteria tested compared to the sample from Muara Rupit (HFMm). The HFMs sample exhibited a strong antibacterial activity towards all Gram negative bacteria (B. cereus, B. subtilis, S. aureus and Micrococcus sp.), with the highest MIC value was obtained at $0.625 \mathrm{mg} / \mathrm{ml}$ against B. subtilis. HFMs also showed a good antibacterial activity against $K$. Pneumonia and P. euroginosa with the MIC value at $5 \mathrm{mg} / \mathrm{ml}$, but weak activity against $E$. Coli and Salmonella sp. $(\mathrm{MIC}=10$ $\mathrm{mg} / \mathrm{ml}$ ). Moreover, the sample of $H$. formicarum tuber from Muara Rupit (HFMm) did not possess antibacterial activity against Gram negative bacterial tested, however, HFMm revealed strong antibacterial activity against all Gram positive bacteria tested ( $B$. cereus, B. subtilis, S. aureus and Micrococcus sp.). The same with HFMs, HFMm revealed the highest antibacterial activity against $B$. subtilis with the MIC value at $0.625 \mathrm{mg} / \mathrm{ml}$. 
Table 2: Antibacterial activity of H. formicarum tuber methanol extracts from Setiu Wetland (HFMs) and Muara Rupit (HFMm) against some pathogenic bacteria.

\begin{tabular}{|c|c|c|c|c|c|c|c|c|c|}
\hline \multirow{2}{*}{ Sample } & \multirow{2}{*}{ Concentration } & \multicolumn{8}{|c|}{ Inhibition zone against bacteria strain } \\
\hline & & B.cer & B.sub & S.aur & Mic.sp & E.coli & K.pne & P.aer & Sal.sp \\
\hline \multirow{6}{*}{ HFMs } & $20 \mathrm{mg} / \mathrm{ml}$ & +++ & +++ & +++ & +++ & + & ++ & ++ & + \\
\hline & $10 \mathrm{mg} / \mathrm{ml}$ & ++ & +++ & ++ & ++ & + & + & + & + \\
\hline & $5 \mathrm{mg} / \mathrm{ml}$ & + & ++ & + & + & - & + & + & - \\
\hline & $2.5 \mathrm{mg} / \mathrm{ml}$ & + & ++ & + & + & - & - & - & - \\
\hline & $1.25 \mathrm{mg} / \mathrm{ml}$ & - & + & - & - & - & - & - & - \\
\hline & $0.625 \mathrm{mg} / \mathrm{ml}$ & - & + & - & - & - & - & - & - \\
\hline \multirow{6}{*}{ HFMm } & $20 \mathrm{mg} / \mathrm{ml}$ & +++ & +++ & +++ & +++ & - & - & - & - \\
\hline & $10 \mathrm{mg} / \mathrm{ml}$ & ++ & +++ & ++ & ++ & - & - & - & - \\
\hline & $5 \mathrm{mg} / \mathrm{ml}$ & + & ++ & + & + & - & - & - & - \\
\hline & $2.5 \mathrm{mg} / \mathrm{ml}$ & + & ++ & + & + & - & - & - & - \\
\hline & $1.25 \mathrm{mg} / \mathrm{ml}$ & - & + & - & - & - & - & - & - \\
\hline & $0.625 \mathrm{mg} / \mathrm{ml}$ & - & + & - & - & - & - & - & - \\
\hline \multirow{6}{*}{ Antibiotic control } & Ampicilin & + & ++ & ++ & ++++ & ++++ & - & - & +++ \\
\hline & Tetracycline & +++ & +++ & - & +++ & +++ & +++ & ++ & +++ \\
\hline & Penicilin & +++ & ++ & + & +++ & ++ & - & - & +++ \\
\hline & Streptomycin & ++ & +++ & - & +++ & ++ & +++ & - & ++ \\
\hline & Gentamycin & +++ & +++ & +++ & +++ & +++ & +++ & +++ & ++ \\
\hline & DMSO & - & - & - & - & - & - & - & - \\
\hline
\end{tabular}

* B. cer: Bacillus cereus, B. sub: Bacillus subtilis, S. aur: Streptococcus aureus, Mic.sp: Micrococcus sp., E. Coli: Escherichia coli, K. pne: Klebsiella pneumonia,

P.aer:Pseudomonas aeruginosa, Sal.sp:Salmonella, sp. *(-) No

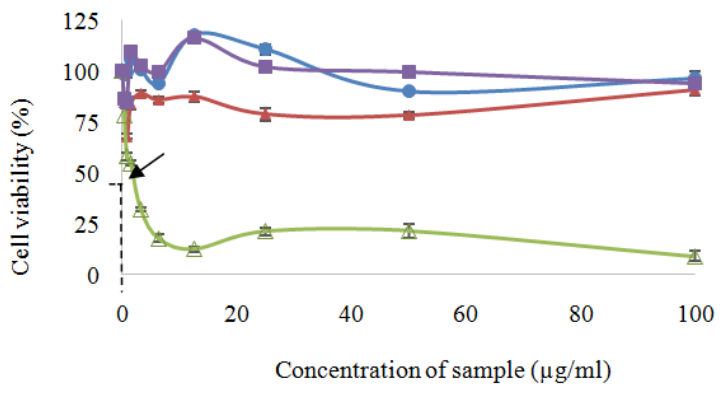

A

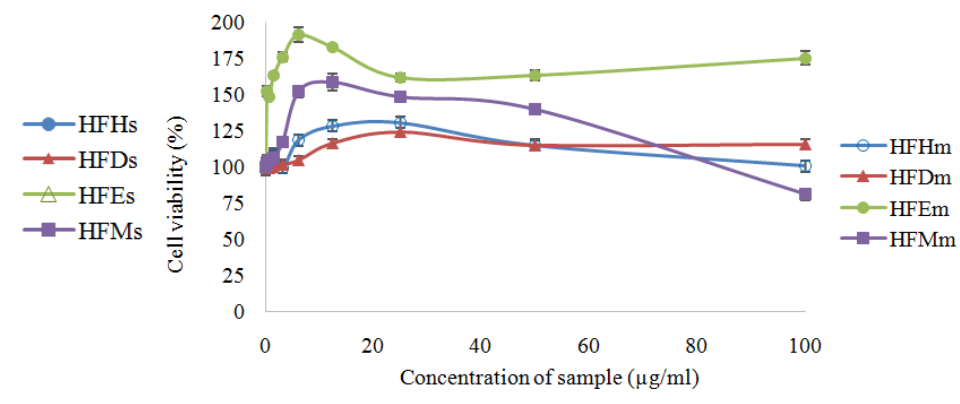

B

Fig. 3: Cytotoxicity property of $H$. formicarum tuber extracts and solvents fractions fromSetiu Wetland (a) and Muara Rupit (b) against MCF-7 cells. Black arrow indicated as $\mathrm{IC}_{50}$ value.
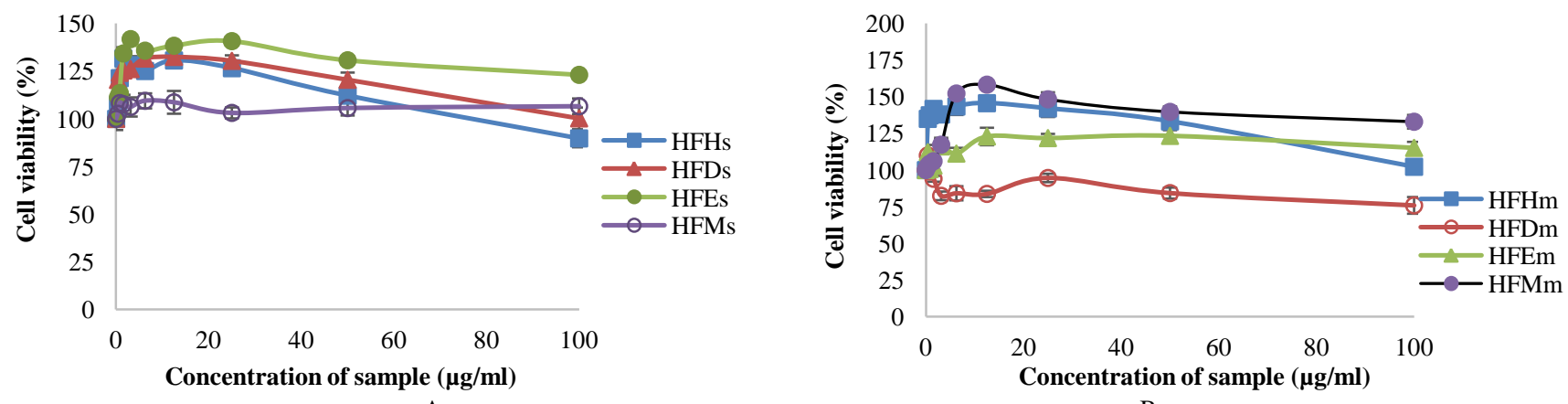

Fig. 4: Cytotoxicity property of $H$. formicarum tuber methanol extracts and fractions fromSetiu Wetland (a) and Muara Rupit (b) against HeLa cells.

\section{Anticancer Potency}

\section{Cytotoxicity effectsagainstMCF-7 and HeLa cells}

The cytotoxicity effects of $H$. formicarum tuber extracts and fractions against MCF-7 cells were shown in Fig. 3a and 3b. It was found that only HFEs from Setiu Wetland exerted inhibitory effects of more than $50 \%$ cell population against MCF-7 cells. There was a dose-dependent reduction in cell viability when the cells were treated with the fraction up to $12.5 \mu \mathrm{g} / \mathrm{ml}$ and remained relatively unchanged at concentrations above $12.5 \mu \mathrm{g} / \mathrm{ml}$. The $\mathrm{IC}_{50}$ value produced by HFEs was $2 \mu \mathrm{g} / \mathrm{ml}$, thus, strongly suggested that the fraction exhibited cytotoxicity effects on the cells as judged by the $\mathrm{IC}_{50}$ value of less than $30 \mu \mathrm{g} / \mathrm{ml}$ (Geran et al., 1979). By contrast, all other $H$. formicarum tuber extracts and fractions showed no cytotoxic activity against MCF-7 cells since there were no concentrations that effectively produced more half-maximal inhibitory effects on total cell population. Interestingly, all of these extracts and fractions except HFDs produced growth stimulatory effects against MCF-7 especially at lower concentrations as shown 
in Fig. 3. As shown in Fig. 4a and 4b, H. formicarum tuber extracts and fractions from both locations produced no cytotoxicity activity against HeLa cells. At all concentrations, the extracts and fractions did not inhibit the cells more than $50 \%$ of total population. HFDm killed the cells but only exhibited a maximum of $25 \%$ cell death against HeLa cells. By contrast, other extracts and fractions increased the growth of the cells to a certain, especially at lower concentrations.

\section{The apoptotic effects of $H$. formicarum tuber from Setiu Wetland against MCF-7 cells}

Annexin V/PI and DAPI staining was used to determine the mode of cell death exerted by $H$. formicarum tuber from Setiu Wetland was via apoptosis (Fig. 5).

(a)

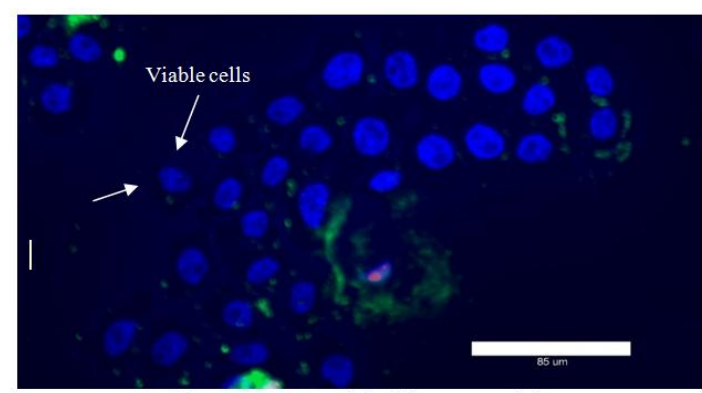

Negative control (without sample)

(b)

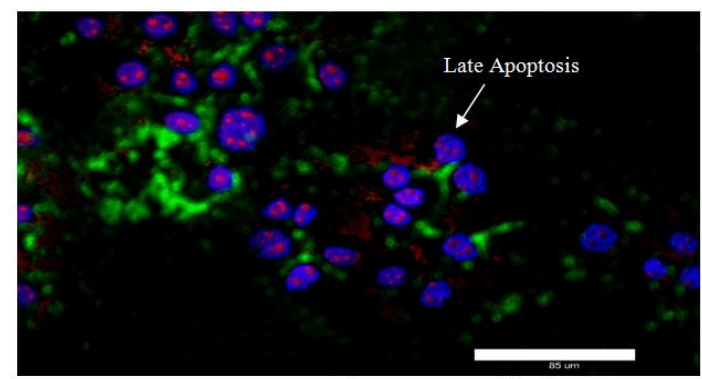

Positive control (Vincristine sulfate)

(c)

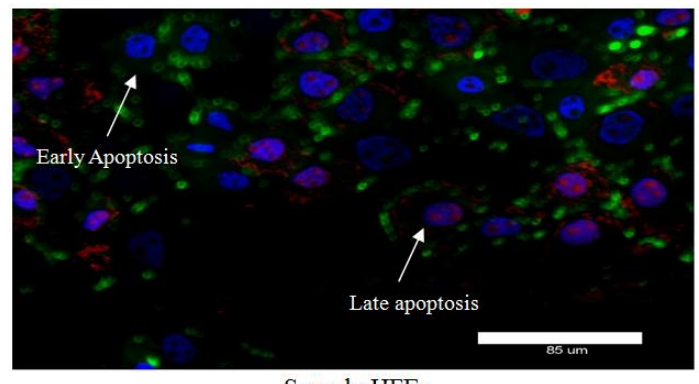

Sample HFEs

Fig. 5: The morphological features of cell died by apoptosis against MCF-7 cells after treated with ethyl acetate fractions HFEs (c) of $H$. formicarum tuber from Setiu Wetland as compared to negative control (a) and positive control (b).

It was found that the cell membrane of cells treated with the extract and vincristine sulfate for $24 \mathrm{~h}$ were stained green indicating that the cell death mediated by these two mediators was via apoptosis. Interestingly, in vincristine sulfate-treated cells, cell nuclei were also stained with PI indicating the cell membrane started to rupture suggesting the cells were in late apoptosis stage, whereby a mixture of PI-stained and non PI-stained nuclei in annexin V-stained cells were observed in the extract-treated cells indicating the cells were in late and early stage of apoptosis, respectively. By contrast, untreated cells did not show any annexin $\mathrm{V}$ and PI staining indicated that the cells were still viable.

\section{DISCUSSION}

Good antibacterial activity was shown by HFMs against all tested bacteria, while HFMm exhibit antibacterial activity against Gram positive bacteria only. The presence of double membrane surrounding on Gram negative bacteria make it more resistant to antibacterial effects, thus the effectiveness on growth inhibition of Gram negative bacteria by $H$. formicarium was in range from weak to good. HFMs exhibit antibacterial activity a range from weak to good at high concentration of extracts on Gram negative bacteria but HFMm does not show the same activity. This probably related to its indigenous growth location (Soeksmanto et al., 2010) and environmental condition such as a concentration of chemical element (phosphorus and nitrogen), irradiation, temperature and water supply. Hypnophytum formicarum scattered from Peninsula of Malaysia to the Solomon Islands which also included Indonesia. As reported by (Prachayasittikul et al., 2008), the fractions of the $H$. formicarum obtained from Thailand shown antibacterial activity on various Gram positive and Gram negative bacteria. Hence, it can be considered that sample of this species which obtained from different places might exhibit different bioactivity. Another species of same Rubiaceae family, Myrmecodia pendans, showed antibacterial activity against bacterial strain Porphyromonas gingivalis ATCC 33277pathogenic bacteria (Kurnia et al., 2016). They have isolated five active antibacteria compounds, namely phenolic, steroid, steroid glycoside, triterpenoid and sesquiterpenoid. Besides, phenolics and tannin, steroids and glycosides also could be responsible for the antibacterial activity of $H$. formicarum tuber from Setiu wetland and Muara Rupit. The previous study revealed that phenolics compound exhibited the antimicrobial activity which is effective as an antimicrobial agent (Rios and Recio, 2005; Sudiono et al., 2015).

All fractions from both places showed no cytotoxic activity against HeLa cells. However, only ethyl acetate fraction from Setiu Wetland (HFEs) showed high cytotoxic activity against MCF-7 cells $\left(\mathrm{IC}_{50}=2 \mu \mathrm{g} / \mathrm{ml}\right)$. According to Geran et al. (1979), the sample which has the $\mathrm{IC}_{50}$ value of less than $30 \mu \mathrm{g} / \mathrm{ml}$ was considered cytotoxic on cells. The morphological features of MCF-7 cells after treated by HFEs and stained by AnnexinV/ PI and DAPI showed that the cell death occurred by apoptosis and in both early and late stages. According to Hingorani et al. (2011), cells were early apoptosis when stained with Annexin V but not stained with PI whereby, cells that were stained with both Annexin $\mathrm{V}$ and PI were in late apoptosis. All cells with intact nucleus were stained by DAPI since it stains all cell nuclei which produce blue 
staining. The result with DAPI positive, and Annexin V/PI negative indicate the viable cells. These results demonstrate that HFEs is capable in inducing both early and late apoptosis in MCF7 cells and has, therefore, a potency to be developed further as an anticancer agent.

Fraction HFEs was found to have high DPPH free radical scavenging compare to standard, Quercetin. Previous studies reported that anticancer property of phenolic compounds is due to their antioxidant activity (Islam et al., 2013; Ghasemzadeh and Jaafar, 2013). Natural phenolics have been found to intervene at all stages of cancer development by their antioxidant action (Dai and Mumper 2010). Senawong et al. (2013) reported the ability of phenolic-rich extracts from $H$. formicarum tuber andits major phenolic compound, sinapinic acid inhibited proliferation of five human cancer cells (HeLa, HT29, HCT116, MCF7and Jurkat cells).

Furthermore, Soeksmanto et al. (2010) demonstrated the capability of $H$. formicarum extract in inhibiting the cancer cell growth due to the presence of flavonoids and tannins compounds. The cytotoxic effect of a flavonoid compound, 7, 3', 5'trihydroxyflavanone from $H$. formicarium on the MCF-7 cells was reported by Abdullah et al. (2010). While Ueda et al. (2002) reported that $H$. formicarum has the anticancer properties by inhibiting the proliferation of human HT-1800 fibrosarcoma cells. According to the phytochemicals screening result, phenols tannins were present in the HFEs could be correlated to its anticancer potency against MCF-7 cells.

Although both samples of $H$. formicarum from Setiu Wetland and Muara Rupit from the same species as well as possessed the same profiles of chemicals constituents, different activity obtained could probably due to the geographical area of sample collection. In addition, different environmental and habitat of $H$. formicarum could affect secondary metabolites produced and activity. Sample of H. Formicarum from Setiu Wetland was live in a mangrove forest near to the beach, while sample of $H$. Formicarum from Muara Rupit was live in an inland forest that far away from the sea.

Hence, cytotoxicity activity of $H$. formicarum tuber from Muara Rupit on another type of cancer cells will be needed to confirm its potency as an anticancer agent.

\section{CONCLUSIONS}

We have demonstrated that both $H$. formicarum tuber from Setiu Wetland and Muara Rupit have strong DPPH free radical scavenging and antibacterial activity. However, only $H$. formicarum tuber from Setiu Wetland have possessed cytotoxic activity againstMCF-7 cells but have no cytotoxicagainst HeLa cells. The morphological feature has proven that MCF-7 cells died by induction of apoptosis. Only $H$. formicarum tuber from Setiu Wetland has potency as an anticancer agent against MCF-7 cell. Different geographical area, environmental and habitat of $H$. formicarum could be effect on their metabolites produced and activity. Further study is required to identify the bioactive compound involved and their contribution on apoptosis at the molecular level.

\section{ACKNOWLEDGEMENT}

We acknowledge to the Institute of Marine Biotechnology, Universiti Malaysia Terengganu for doing research and using laboratory instruments. Special thanks dedicated to Mrs. Herina Yuni Utami, M.Pd for donating sample from Muara Rupit, Indonesia for this current study.

\section{Financial support and sponsorship: Nil.}

Conflict of interests: The authors declare no conflict of interest.

\section{REFERENCES}

Abdullah H, Pihie AHL, Hohman J, MolnarJ.A natural compound from Hydnophytum formicarium induces apoptosis of MCF-7 cells via up-regulation of Bax. Cancer Cell Int, 2010; 10(14): 1-6.

Andriani Y, Effendy AWM, Tengku Muhammad TS, Habsah M.Antibacterial, Radical scavenging activities and cytotoxicity properties of Phaleria macrocarpa (Scheff.) Boerl.Leaves in HepG2 Cell lines. IJPSR, 2011; 2(7):1700-1706.

Andriani Y, Ramli NM, Syamsumir DF, Kassim MNI, Jaafar J, Nur Asniza Azis, Marlina L, Musa NS, Mohamad H. 2015. Phytochemical analysis, antioxidant, antibacterial and cytotoxicity Activities of keys and cores part of Pandanus tectorius fruits. Arab J Chem. http://doi.org/10.1016/j.arabjc.2015.11.003.

Dai $\mathrm{J}$ and Mumper RJ. Plant Phenolics: Extraction, Analysis and Their Antioxidant and Anticancer Properties. Molecules, 2010; 15: 7313-7352.

Darwis D, Hertiani T, Samito E.The effects of Hydnophytum formicarum ethanolic extract towards lymphocyte, vero and T47d cells proliferation in vitro.JAPS, 2014; 4(06): 103-109.

Ghasemzadeh A andJaafarHZE.Profiling of phenolic compounds and their antioxidant and anticancer activities in pandan (Pandanus amaryllifolius Roxb.) extracts from different locations of Malaysia.BMC Complementary Altern Med, 2013; 13: 341.

Globocan. Available at: http://globocan.iarc.fr/old/FactSheets/cancers/cervix-new.asp. [Accessed 15 November 2014].

Hingorani R, Deng J, Elia J, McIntyre C, Mittar D. Detection of apoptosis using the BD annexin V FITC assay on the BD FACSVerse ${ }^{\mathrm{TM}}$ System: Application note. BD Bioscience. 2011: 1-12.

Islam S, Nasrin S, Khan MA, Sakhawat Hossain ASM, Islam F, Khandokhar P, Mollah MNH, Rashid M, Sadik G, Abdur Rahman MdA, Khurshid Alam AHM. Evaluation of antioxidant and anticancer properties of the seed extracts of Syzygium fruticosum Roxb. growing in Rajshahi, Bangladesh. BMC Complementary Altern Med, 2013; 13:142.

Kumaran A and Karunakaran RJ. Food Chemistry Antioxidant and free radical scavenging activity of an aqueous extract of Coleus aromaticus.Food Chem, 2016; 97: 109-114.

Kurnia D, Yuda IP, Sumiarsa D, Dharsono HDA, Satari MH. Antibacterial Porphyromonas gingivalis ATCC 33277 Terpenoid from Sarang Semut (Myrmecodia pendans). NPC, 2016;11(0): 1-4.

Prachayasittikul S, Buraparuangsang P, Worachartcheewan A, Chartchalerm I-Na-A, Ruchirawat S, Prachayasittikul V.Antimicrobial and Antioxidative Activities of Bioactive Constituents from Hydnophytum formicarum Jack. Molecules, 2008; 13:904-921.

Rios JL and Recio MC. Perspective paper, Medicinal plants and antimicrobial activity. J Ethnopharmacol,2005; 100: 80-84.

Senawong T, Misuna S, Khaopha S, Nuchadomrong S, Sawatsitang P, Phaosiri C, Surapaitoon A, Sripa, B. Histone deacetylase (HDAC) inhibitory and antiproliferative activities of phenolic-rich extracts derived from the rhizome of Hydnophytum formicarum Jack.: sinapinic 
acid acts as HDAC inhibitor. BMC Complementary and Alternative Medicine, 2013; 13:232.

Soeksmanto A, Subroto MA, Wijaya H, Simanjuntak. P. Anticancer activity for extracts of Sarang-Semut plant (Myrmecodia pendens) to HeLa and MCM-B2 cells. Pakistan J Biol Sci, 2010; 13: 148151

Sudiono J, Oka CT, Trisfilha P. The Scientific Base of Murmecodia pendans as Herbal Remedies.Br J Med Medic Res, 2015; 8(3): 230-237.

Ueda JY, Tezuka Y, Banskota AH, Tran QL, Tran QK, Hariyama Y, Saiki I, Kadota S.Antiproliferative activity of Vietnamese medicinal plants. Biol Pharm Bull, 2002;25: 753-760.

Yadav RNS and Agarwala M. Phytochemical analysis of some medicinal plants. J Phytol.2011; 3(12): 10-14.

American Cancer Society, n.d. Cancer facts and figures 2016. Available at: https://www.cancer.org/research/cancer-facts-statistics/allcancer-facts-figures/cancer-facts-figures-2016.html. [Accessed 8 August2017].

American Cancer Society, n.d. Breast ancer facts and figures 2015-2016. Available at: https://www.cancer.org/.../cancer.../cancer.../breast-cancer.../breast-cancerfacts-and-figures. [Accessed 2 August 2017].

World Health Organization, n.d.Cancer.Available at: http://www.who.int/mediacentre/factsheets/fs297 /en/index.html. [Accessed 15 November 2014]
World Health Organization, n.d. Cancer. Available at http://www.who.int/mediacentre/factsheets/fs297/en/ [Accessed 2 August 2017].

WWF, 2008. Sustainable Management of Setiu Wetland. Available at: http://www. wwf.org.my.[Accessed 14 November 2014]

\section{How to cite this article:}

Andriani Y, Mohamad H, Kassim M, Rosnan N, Syamsumir D, Saidin J, Muhammad T, Amir H. Evaluation on Hydnophytum formicarum Tuber from Setiu Wetland (Malaysia) and MuaraRupit (Indonesia) for Antibacterial and Antioxidant activities, and anticancer Potency against MCF-7 and HeLa Cells. J App Pharm Sci, 2017; 7 (09): 030-037. 